\title{
Religious Leader's Support toward Individual at Risk of HIV/AIDS to Attend Voluntary Counselling and Testing Service
}

\author{
Imelda F E Manurung1 ${ }^{*}$, Catharina Umbul Wahyuni², Ari Probandari ${ }^{3}$
}

\author{
${ }^{1}$ Public Health Program, Faculty of Public Health, Universitas Nusa Cendana, Kupang, Indonesia \\ ${ }^{2}$ Department of Public Health, Faculty of Medicine, Universitas Sebelas Maret, Surakarta, Indonesia \\ ${ }^{3}$ Department of Epidemiology, Faculty of Public Health, Universitas Airlangga, Surabaya, Indonesia
}

\begin{abstract}
Religious leader is a figure who is believed to have the gift of healing. A person with illness will follow any advice the religious leader gives for his/her recovery. Based on the phenomenon, religious leader is a potential local figure to give support for individuals at risk of human immunodeficiency virus (HIV) and acquired immune deficiency syndrome (AIDS). This study aimed to determine factors related to religious leader's support toward individuals at risk of HIV and AIDS to attend voluntary counselling and testing (VCT) service. This study was an observational analytical with cross-sectional design. The population of this study was religious leader in Kupang City. The sample size was 70 people selected through random sampling technique. The data were collected using questionnaire and analyzed using chi-square and multiple logistic regression test. Factors significantly related to the religious leaders supports' for individuals at risk of HIV and AIDS to get VCT were knowledge $(\mathrm{OR}=9.01 ; 95 \% \mathrm{Cl}=1.73-47.07)$, servant leadership $(\mathrm{OR}=11.67 ; 95 \% \mathrm{Cl}=2.44-55.84$, trust $(\mathrm{OR}=$ $11.55 ; 95 \% \mathrm{Cl}=2.35-56.70)$ and perception (OR $=6.12 ; 95 \% \mathrm{Cl}=1.26-29.71)$. Social capital had no significant effect on the religious leader support's (OR $=1.06 ; 95 \% \mathrm{Cl}=0.22-5.12$ ). It is necessary to improve religious leader's knowledge of HIV and AIDS.
\end{abstract}

Keywords: religious leader's support, voluntary counselling and testing

\section{Introduction}

The number of human immunodeficiency virus (HIV) and acquired immune deficiency syndrome (AIDS) cases in Indonesia in 2016 reached 319,103. The number was greater than the number in 2015 which reached 268,185 cases. ${ }^{1}$ Cases of HIV and AIDS have been found in throughout Indonesia and the number increases every year. ${ }^{2}$ The cumulative number of HIV and AIDS cases in East Nusa Tenggara Province increased from 4,056 cases in 2015 to 4,581 cases in $2016 .{ }^{3}$ The increase is the reason that HIV test is very important as the first service of preventing HIV and AIDS transmission. ${ }^{4}$ HIV test is an essential entry point for prevention, care, support and treatment services. ${ }^{5}$

The lack of information about HIV and lack of support to utilize voluntary counselling and testing (VCT) services was a major factor of behavior of people at risk to have HIV test. ${ }^{5}$ The study was supported by a study which showed that willingness and social support affected a person's behaviour. ${ }^{6}$

Revealing individuals at risk of HIV/AIDS and providing support for them to attend VCT service can basically

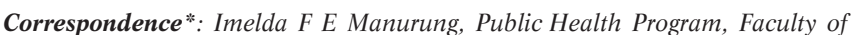
Public Health, Universitas Nusa Cendana, Adisucipto Street, Kupang, Indonesia, E-mail: imelda.manurung@staf.undana.ac.id,Phone: +62-812-3799-9910 be done by the community, given that HIV/AIDS cases in East Nusa Tenggara Province are found in children and housewives. The trend continues to increase with the increase in the number of children infected with HIV/AIDS as many as 103 in 2015 to 115 in 2016. As in housewives, the number reaches 1,011 in 2016, increasing from 970 in $2015 .^{7}$

Some of East Nusa Tenggara Province communities are very dependent on religious leaders in addition to health workers. Religious leader is a figure who is believed to have the gift of healing and be able to help individuals overcome the struggles of life. The people believe that religious leaders have the gift to help them repent and live a better life. The ministry performed by religious leaders is the service of love so as to make people feel comfortable and not judged when they want to recover.

Church leaders, pastors and congregations had the power of doctrine, caring, and mental recovery, using their beliefs in supporting people with HIV/AIDS. It encourages this study to prove that religious leaders in East Nusa Tenggara Province also have the power to be empowered in health programs. $.8,9$

Received : March 24, 2019

Accepted : July 16, 2019

Published: May 25, 2020 
People were willing to follow the advice delivered by church ministers regarding HIV prevention. To the community, church minister is a very trusted person greatly accepted by the local community. ${ }^{10}$

Religious leader's support is the availability to give encouragement to individual at risk HIV/AIDS to attend VCT service. These support can be emotional, information, appraisal and instrument support. Religious leader's support was influenced by the variables of motivation, emotional engagement, knowledge, skills, confidence, leadership and community support. ${ }^{11-13}$ Social support by utilizing one's leadership in running a program affected the program's sustainability. ${ }^{14}$ In addition to leadership, social capital factors consisting of trust, norms and networking are the theoretical foundations to consider in making various activities aimed at building society. ${ }^{15}$ The aim of this study was to to determine the related factors of religious leader supports' for individuals at risk of HIV/AIDS to attend VCT services in East Nusa Tenggara Province.

\section{Method}

The study was conducted in Kupang, the capital city of East Nusa Tenggara Province with the highest HIV/AIDS cases compared to other districts/cities. Kupang population in 2016, according to the the Provincial Statistics of East Nusa Tenggara, amounted to 384,112 , consisting of 196,602 male and 187,510 female. Kupang population is mostly migrants who make a living as a taxi driver, motorbike taxi driver, trader, fisherman, farmer and construction worker. ${ }^{16}$ HIV/AIDS cases were found in any village in Kupang. Most of the cases were found in housewife. There were 11 primary health care in Kupang, supported by 34 subsidiary primary helath care spread across the sub-districts. VCT services cannot be conducted at the primary helath care so that HIV/AIDS patient should be referred to the local hospital. There were three hospitals that provide VCT services. In general, individuals who do VCT are referred by non-governmental organization (NGO) and health workers. It has to be noted that NGO may not run their HIV/AIDS program in Kupang for long.

This study was an observational analytical study with cross-sectional design to determine the effect of knowledge, leadership in serving, social capital, perception and trust on religious leader's supports. The data were collected through interview using questionnaire to examine the knowledge, consisting of multiple choice of 'true / false', social capital, leadership in serving, perception, trust and religious leaders supports', referring to likert scale. The duration of the interview was not longer than 30 minutes.

Validity and reliability tests of the questionnaire were conducted to 30 respondents in Soe, South Central Timor
District. The validity test performed was correlation test, if the value of corrected item total correlation $>0.361$, the statement was said to be valid. The coefficient value was said to be reliable if Cronbach alpha $>0.60 .{ }^{17}$

The population of the study was religious leaders registered in the prayer fellowship at the East Timor Evangelical Church, Kupang. There were 70 Masehi Injil Churches in Timor (Gereja Masehi Injil di Timor / GMIT) in Kupang. Each church commonly has two religious leaders. Prayer service is performed regularly once a week in prayer meeting which is open for anyone. If a sick person needs prayer service other than the one in the schedule, religious leaders are willing to pay a visit to their house to give a prayer service.

The sample size was determined through hypothesis test where large sample based on two population proportion. ${ }^{18}$ Based on the description of the formula by Hulley, et al., ${ }^{19}$ the sample size (n) obtained was 70 people. The initial step of determining sample was sampling frame to 160 religious leaders and followed by random sampling to select 70 religious leaders. Random sampling was also conducted to select three individuals who had been served by religious leaders within the previous month (December 2015) and other three people representing the community located in the same village as the religious leaders. The measurements for trust, perception and leadership in serving were derived from the mean value of three individuals served by religious leaders. The measurements for knowledge and religious leaders' supports were derived by directly addressing the religious leaders. While, the measurement for social capital was obtained from the mean value of three religious leaders' closest neighbors.

The study was conducted in August 2015 - May 2016. In order to measure the variables of knowledge and religiuos laeders' supports, questionnaire was distributed to a total of 70 religious leaders. As for measuring trust, leadership in serving and perception, questionnaire was to be filled in by individuals who had been served by religious leaders. Questionnaire regarding social capital was addressed to communities living close to the religious leaders.

The method of data collection used in this study was distributing questionnaire to collect the data on health literacy, leadership in serving, social capital, perception, trust and religious leaders supports'. The questionnaire for collecting the data on knowledge consisted of questions to be answered by 'true / false'. Variables of social capital, leadership in serving, perception, trust and religious leader supports' referred to likert scale modification. ${ }^{20}$

Questionnaire on knowledge consisted of 16 questions in which each correct anwer would be given score 1 while each wrong answer would be given score 0 . Questionnaire on religious leaders supports' consisted of 8 statements, 
questionnaire on social capital consisted of 13 statements, questionnaire on leadership in serving consisted of 19 statements, questionnaire on perception consisted of 5 statements and questionnaire on trust consisted of 5 statements. Scoring was based on Likert scale with 5 choices of answers. For favorable questions, the option 'strongly agree' had a value of 5 , the option 'agree' had a value of 4 , the option 'neutral' had a value of 3 , the option 'disagree' had a value of 2 and the option 'strongly disagree' had a value of 1 . For unfavorable questions, the option 'strongly agree' had a value of 1, the option 'agree' had a value of 2, the option 'neutral' had a value of 3 , the option 'disagree' had a value of 4 , and the option 'strongly disagree' had a value of 5 .

The assessment proceeded by using the midpoint score criteria, e.g., the highest score - the lowest score then the result is divided by 2 . If the value obtained is less than the midpoint score, it is categorized as 'poor' and if the value obtained is greater than the midpoint score, it is categorized as 'good'. If the highest score of knowledge is 16 and the lowest score is zero, then the midpoint score for knowledge is 8 . Knowledge is categorized as good if the value is $>8$, religious leaders supports' is categorized as good if the value is $>16$, leadership in serving is categorized as good if the value is $>38$, social capital is categorized as good if the value is $>26$, perception is categorized as good if the value is $>10$, and trust is categorized as good if the value is $>10$.

Multivariate analysis was conducted to analyze the effect of knowledge, leadership in serving, social capital, perception and trust on religious leaders' supports. Multivariate analyis using multiple logistic regression was performed on variable that showed $\mathrm{p}$-value $<0.25$ during bivariate analysis with chi-square test. Ethical clearance was obtained from the Faculty of Public Health, Universitas Airlangga, Indonesia with serial number 441KEPK. A written informed consent was received from all religious leaders.

\section{Results}

The results of distributions' frecuency in Table 1 showed that $51.4 \%$ respondents are females and $85.7 \%$ respondents went to senior high school or higher. Then $71.4 \%$ respondents were over 40 years old and were housewives/retirees. For independent variables, respondents' leadership in serving, trust, perception and social capital were mostly in good category. However, the knowledge of $57.2 \%$ respondents was in poor category.

Table 2 shows respondents' characteristics do not contribute on religious leaders' supports. Thus, it can be concluded that the characteristics of respondents are not an interference factor. The factors related religious leaders' supports indicated that all variables were related to the religious leaders supports'. Servant leadership has the highest odd ratio $(\mathrm{OR})$ value.

However, the results of multivariate analysis in Table 3 showed that social capital was not related to religious leaders' supports $(\mathrm{OR}=1.062 ; 95 \% \mathrm{CI}=0.223$ - 5.125). While, in bivariate analysis, social capital variables have a relationship with religious leaders' supports ( $\mathrm{p}$-value $=$ $0.01 ; 95 \% \mathrm{CI}=1.31-9.83$ ). On the other hand, knowledge, leadership in serving, trust, and perception were related to religious leaders supports'. The variable of leadership in serving had a greater likelihood of 11.67 times to religious leaders supports' for individuals at risk of HIV and AIDS to attend VCT (OR $=11.662 ; 95 \% \mathrm{CI}$ $=2.436-55.838)$, the relation was stronger than the ones' of other variables.

\section{Discussion}

The results of this study indicated that good knowledge could increase religious leaders supports' for individual at risk of HIV to attend VCT service. Knowledge is information relating to risk factors of HIV transmission, prevention and VCT behavior. The component of religious leaders supports' is the providing information on HIV transmission, motivation, assessment and real assistance for VCT.

One will first find out about HIV information before he decides to provide support to others to do VCT. The

Table 1. The Distribution of Respondents' Frequency Based on Characteristics and Factors of Religious Leader's Supports

\begin{tabular}{|c|c|c|c|}
\hline Variable & Category & $\mathrm{n}=\mathbf{7 0}$ & $(\%)$ \\
\hline \multicolumn{4}{|l|}{ Respondent's characteristics } \\
\hline \multirow[t]{2}{*}{ Sex } & Male & 34 & 48.6 \\
\hline & Female & 36 & 51.4 \\
\hline \multirow[t]{2}{*}{ Age } & $\leq 40$ years & 20 & 28.6 \\
\hline & $>40$ years & 50 & 71.4 \\
\hline \multirow[t]{2}{*}{ Occupation } & Employed & 20 & 28.6 \\
\hline & Unemployed & 50 & 71.4 \\
\hline \multirow[t]{2}{*}{ Education } & $<$ Senior high school & 10 & 14.3 \\
\hline & $\geq$ Senior high school & 60 & 85.7 \\
\hline \multirow[t]{2}{*}{ Ministry } & $<5$ years & 16 & 22.9 \\
\hline & $\geq 5$ years & 54 & 77.1 \\
\hline \multicolumn{4}{|c|}{ Factors of religious leaders's support } \\
\hline \multirow[t]{2}{*}{ Knowledge } & Poor & 40 & 57.2 \\
\hline & Good & 30 & 42.8 \\
\hline \multirow[t]{2}{*}{ Social capital } & Poor & 28 & 40.0 \\
\hline & Good & 42 & 60.0 \\
\hline \multirow[t]{2}{*}{ Leadership } & Poor & 29 & 41.4 \\
\hline & Good & 41 & 58.6 \\
\hline \multirow[t]{2}{*}{ Perception } & Poor & 31 & 44.2 \\
\hline & Good & 39 & 55.7 \\
\hline \multirow[t]{2}{*}{ Trust } & Poor & 30 & 42.9 \\
\hline & Good & 40 & 57.1 \\
\hline \multicolumn{4}{|l|}{ Support } \\
\hline \multirow[t]{2}{*}{ Information support } & Poor & 38 & 54.3 \\
\hline & Good & 32 & 45.7 \\
\hline \multirow[t]{2}{*}{ Emotional support } & Poor & 31 & 44.3 \\
\hline & Good & 39 & 55.7 \\
\hline \multirow[t]{2}{*}{ Appraisal support } & Poor & 32 & 45.7 \\
\hline & Good & 38 & 54.3 \\
\hline \multirow[t]{2}{*}{ Instrumental support } & Poor & 37 & 52.9 \\
\hline & Good & 33 & 47.1 \\
\hline
\end{tabular}


Table 2. Bivariate Analysis of Factors Related to Religious Leader's Support toward Individual at Risk HIV/AIDS to Attend Voluntary Counselling and Testing Service

\begin{tabular}{|c|c|c|c|c|c|c|c|c|}
\hline \multirow{3}{*}{ Variable } & \multirow{3}{*}{ Category } & \multicolumn{4}{|c|}{ Religious Leaders' Supports } & \multirow{3}{*}{ OR } & \multirow{3}{*}{$\mathbf{9 5} \% \mathbf{C I}$} & \multirow{3}{*}{ p-value } \\
\hline & & \multicolumn{2}{|c|}{ Poor } & \multicolumn{2}{|c|}{ Good } & & & \\
\hline & & $\mathbf{n}$ & $\%$ & $\mathbf{n}$ & $\%$ & & & \\
\hline \multirow[t]{2}{*}{ Sex } & Male & 15 & 21.5 & 19 & 27.1 & 0.882 & $0.344-2.262$ & 0.794 \\
\hline & Female & 17 & 24.3 & 19 & 27.1 & & & \\
\hline \multirow[t]{2}{*}{ Age } & $\leq 40$ years & 9 & 12.9 & 11 & 15.7 & 0.960 & $0.339-2.722$ & 0.940 \\
\hline & $>40$ years & 23 & 32.8 & 27 & 38.6 & & & \\
\hline \multirow[t]{2}{*}{ Occupation } & Employed & 7 & 10.0 & 13 & 18.6 & 0.538 & $0.184-1.575$ & 0.255 \\
\hline & Unemployed & 25 & 35.7 & 25 & 35.7 & & & \\
\hline \multirow[t]{2}{*}{ Education } & $<$ Senior high school & 5 & 7.1 & 5 & 7.1 & 1.222 & $0.320-4.667$ & 0.769 \\
\hline & $\geq$ Senior high school & 27 & 38.6 & 33 & 47.2 & & & \\
\hline \multirow[t]{2}{*}{ Ministry } & $<5$ years & 8 & 11.4 & 8 & 11.4 & 1.250 & $0.409-3.821$ & 0.695 \\
\hline & $\geq 5$ years & 24 & 34.3 & 30 & 42.9 & & & \\
\hline \multirow[t]{2}{*}{ Knowledge } & Poor & 26 & 37.1 & 14 & 20.0 & 7.429 & $2.459-22.443$ & 0.001 \\
\hline & Good & 6 & 8.6 & 24 & 34.3 & & & \\
\hline \multirow[t]{2}{*}{ Social capital } & Poor & 18 & 26.1 & 10 & 7.0 & 3.600 & $1.318-9.831$ & 0.011 \\
\hline & Good & 14 & 20.0 & 28 & 40.0 & & & \\
\hline \multirow[t]{2}{*}{ Leadership } & Poor & 23 & 32.8 & 6 & 8.6 & 13.630 & $4.257-43.638$ & 0.001 \\
\hline & Good & 9 & 12.9 & 32 & 45.7 & & & \\
\hline \multirow[t]{2}{*}{ Perception } & Poor & 21 & 30.0 & 10 & 14.3 & 5.345 & $1.915-14.919$ & 0.001 \\
\hline & Good & 11 & 15.7 & 28 & 40.0 & & & \\
\hline \multirow[t]{2}{*}{ Trust } & Poor & 23 & 32.8 & 7 & 10.0 & 11.317 & $3.673-34.875$ & 0.001 \\
\hline & Good & 9 & 12.9 & 31 & 44.3 & & & \\
\hline
\end{tabular}

Notes: OR = Odds Ratio, $\mathrm{CI}=$ Confidence Interval, Level of significant $<0.05$

Table 3. Multivariate Analysis of Factors related to Religious Leader's Support toward Individual at Risk HIV/AIDS to Attend Voluntary Counselling and Testing Service

\begin{tabular}{|c|c|c|c|c|c|c|}
\hline Variable & Category & $\beta$ & SE & p-value & Adjusted OR & 95\% CI \\
\hline \multirow[t]{2}{*}{ Knowledge } & Poor & & & & ref & \\
\hline & Good & 2.199 & 0.843 & 0.009 & 9.018 & $1.728-47.066$ \\
\hline \multirow[t]{2}{*}{ Leadership } & Poor & & & & ref & \\
\hline & Good & 2.456 & 0.799 & 0.002 & 11.662 & $2.436-55.838$ \\
\hline \multirow[t]{2}{*}{ Perception } & Poor & & & & ref & \\
\hline & Good & 1.812 & 0.806 & 0.025 & 6.122 & $1.261-29.716$ \\
\hline \multirow[t]{2}{*}{ Trust } & Poor & & & & ref & \\
\hline & Good & 2.446 & 0.812 & 0.003 & 11.546 & $2.351-56.707$ \\
\hline Constant & & -4.457 & & 0.001 & 0.012 & \\
\hline
\end{tabular}

Notes: $\mathrm{SE}=$ Standard Error, $\mathrm{OR}=$ Odds Ratio, $\mathrm{CI}=$ Confidence Interval, Ref $=$ Reference

information includes information related to the benefits of VCT, whether VCT harms or benefits others. Knowledge is the foundation for religious leaders to engage in various humanitarian activities. In general, religious leaders' knowledge on HIV and AIDS was poor. Most respondents had their answers wrong for questions on risk factors of HIV transmission. According to the religious leaders, HIV was transmitted not only through unsafe sex but also shaking hands, clothes and other personal stuffs. The religious leaders answers relating to stigma were generally good. The religious leaders accepted and treated anyone with love. Religious leaders's positive perception on individuals at risk of HIV and AIDS was in line with the religious leaders to give support to attend VCT and was in good category. Knowledge and accep- tance of individuals at risk of HIV and AIDS provided the basis for religious leaders to provide support for individuals at risk of HIV and AIDS. ${ }^{21}$

Knowledge is individual's ability to understand and communicate health related information and make decisions related to the information. ${ }^{22}$ One's knowledge will encourage strategic measurement to promote health issues across sectors. A study in West Virginia proved that good knowledge could encourage community to have a safe sex. ${ }^{23}$ Knowledge is one dimension to realize social support. ${ }^{24}$ Social support is a condition in which one has the skills, knowledge and power to take action to help themselves and influence the lives of others as an HIV preffention effort among sex workers. The conclusion of the study showed that the better the knowledge, 
the better the religious leaders' support to engage in HIV prevention activities. ${ }^{25,26}$

The results showed that social capital did not affect the improvement of religious leaders' support for individuals at risk of HIV and AIDS to attend VCT. This study showed such results because, statistically, the respondents' answers were very homogeneous, most answers were in good category and good enough category, so that it influenced the results of statistical analysis. The homogeneous data indicated that social capital did not affect religious leaders' support. The results are in line with the study by Richards and Reed, ${ }^{27}$ conducted on volunteers in the United Kingdom which concluded that social capital did not always have a positive effect on the empowerment of volunteer. The potential and interaction of fellow volunteers could actually be used to develop the social capital that existed in their environment. Study in Tanzania also proved that social capital negatively affected ones' efforts to prevent HIV. ${ }^{28}$

The results of this study indicated that leadership in serving was a factor that could improve religious leaders supports' for individuals at risk of HIV and AIDS. Religious leaders' leadership in serving was manifested from their spiritual capital. Spiritual capital is religious leaders' spiritual life associated with the life of prayer, the contemplation of the word of God, fasting and activities of a personal relationship with God. The results of an intimate personal contact with God give a message to religious leaders to serve others with love and humility. The calling to serve is a factor for religious leaders to provide support for individuals at risk of HIV and AIDS. ${ }^{29}$ The religious leaders' gift of healing is a blessing to others. This is the basis for religious leaders to provide support for individuals at risk of HIV and AIDS. 30

Religious leaders are able to help others understand problems and see the problems thoroughly, awake and change others by giving rational reasons. ${ }^{31}$ The ability to persuade is also reflected in the ability of religious leaders to persuade individuals to achieve noble goals, not only in daily activities, but also in the long run. ${ }^{32}$ The results of this study are also in line with the study by Benawa, ${ }^{33}$ in Jakarta which indicated that the relationship with others based on faith would affect a one's empowerment to be involved in giving support to others. Religious leaders' leadership in serving is a leadership that comes from a sincere feeling to serve. The motivation to serve is that the needs of others can be met, e.g., making them more mature, healthy, free, and independent. Social support by utilizing one's leadership in running a program will ensure the sustainability of the program to last longer. ${ }^{14,34}$

A study conducted by Campbell, et al., ${ }^{35}$ showed that one relied on religious leader for keeping secrets, so that they would be open regarding their personal life and were willing to do what the religious leader told them. One's perception of a health program would affect one's confidence to engage to the program. ${ }^{36,37}$ Perception of HIV affected one's confidence to protect themselves from HIV. 38 The trust that one receives is one of the factors of the realization of social support. ${ }^{35}$ The relationship between religious leader and the individual being served is a trust-based relationship. The trust gained from the individual being served becomes the basis for religious leader to engage to the lives of the individuals. One has the willingness to share their problems and follow any advice only from those they trust. ${ }^{39}$ This condition makes religious leaders want to get more involved to help individuals solve their problems. Trust gained by religious leaders affected the realization of supporting for individual at risk HIV and AIDS to attend VCT service. The greater the trust gained, the greater the supporting of religious leader.

The strength of this study is finding potential community-based leaders who can be empowered to support individuals at risk of HIV and AIDS to attend VCT service. The things to note to avoid bias is when looking for a religious leader with special gift according to people's perceptions. Deeper information from the community is very important to obtain, so that it is not wrong to determine whether the person is truly a religious leader with the gift of healing from God.

\section{Conclusion}

Good leadership in serving, knowledge, trust and perception from community's assesment are the potentials of religious leaders to support individuals at risk of HIV and AIDS to attend VCT service. In addition, knowledge of religious leader is a factor that contributes to providing support for people at risk of HIV to attend VCT service. However, there are still many religious leaders with poor knowledge, so efforts need to be made to increase knowledge related to HIV and AIDS. Efforts are made such as training and involving religious leader in HIV prevention programs.

\footnotetext{
Abbreviations

HIV: Human Immunodeficiency Virus; AIDS: Acquired Immune Deficiency Syndrome; VCT: Voluntary Counselling and Testing; NGO: Non-governmental Organization; GMIT: Gereja Masehi Injil di Timor; OR: Odd Ratio.

\section{Ethics Approval and Consent to Participate}

Ethical clearance was obtained from the Faculty of Public Health Universitas Airlangga, Indonesia. The number of ethical clearance is 441-KEPK. A written informed consent was received from all religious leaders.
} 


\section{Competing Interest}

Author declares that there are no significant competing financial, professional, or personal interests that might have affected the performance or presentation of the work described in this manuscript.

\section{Availability of Data and Materials}

Research data can be provided upon reasonable request.

\section{Authors' Contribution}

Imelda F E Manurung designed the study, developed the data collection tools, conducted the interviews, data analysis and drafted the manuscript. Ari Probandari contributed to the design of the study, developed the methodology, and helped designing the data collection tools. Chatarina Umbul Wahyuni critically reviewed all aspects of the study and assisted in writing the manuscript. All of the authors have approved the final manuscript.

\section{Acknowledgment}

The authors would like to thank Masehi Injil Church in Timor (Gereja Masehi Injil di Timor / GMIT) in Kupang for their support. Furthermore, the authors are grateful to the AIDS Commission of East Nusa Tenggara Province for their support to provide data and materials. The authors would like to thank all respondents who kindly consented to participate in this study. We sincerely thank religious leader and community in Kupang city for their support for individual at risk of HIV/AIDS to get VCT.

\section{References}

1. Kementerian Kesehatan Republik Indonesia. Rencana aksi nasional kolaborasi TB-HIV, 2015-2019. Jakarta: Kementerian Kesehatan Republik Indonesia Direktorat Jenderal Pengendalian Penyakit dan Penyehatan Lingkungan; 2015. p.1.

2. Direktorat Jendral Pengendalian Penyakit. Laporan situasi perkembangan HIV/AIDS dan Penyakit Infeksi Menular Seksual di Indonesia Oktober-Desember 2016; 2016. p. 8-20.

3. Komisi Penanggulangan HIV/AIDS Provinsi NTT. Laporan kasus HIV/AIDS di Provinsi Nusa Tenggara Timur Tahun 2016; 2016. p. 1-5.

4. Burhan R. Health service utilization in women living with HIV/AIDS. Kesmas: Jurnal Kesehatan Masyarakat Nasional. 2013; 8 (1): 33-8.

5. Mtenga S, Exaver, A, Kakoko D, Geubbels E. Social cognitive determinants of HIV voluntary counselling and testing uptake among married individuals in Dar es Salaam Tanzania: theory of planned behaviour (TPB). BMC Public Health. 2015; 15 (213): 1-8.

6. Okeafor CU, Okeafor IN. Trends in sexual risk behaviour, HIV knowledge and testing among reproductive-aged women in Nigeria: DHS 2003-2013. HIV \& AIDS Review. 2017; 16 (2): 107-11.

7. Mugomeri E, Chatanga P, Notoane MJ. Reported quality of life of HIVpositive people in Maseru, Lesotho: the need to strengthen social protection programmes. HIV \& AIDS Review. 2016; 15 (2): 61-8.

8. Abara W, Coleman JD, Fairchild A, Gaddist B, White J. A Faith-based community partnership to address HIV/AIDS in the Southern United States: implementation, challenges, and lessons learned. Journal Religious Health. 2015; 54 (1): 122-33.

9. Ramirez-Johnson J, Diaz HL, Feldman JB, Ramirez-Jorge J. Empowering
Latino church leaders to deal with the HIV-AIDS crisis: a strengths-oriented service model. Journal of Religious Health. 2013; 52 (2): 570-88.

10. Stewart MJ. Pastor and lay leader perceptions of barriers and supports to HIV ministry maintenance in an African American Church. Journal of Religious Health. 2014; 53 (2): 317-25.

11. Dupont S, Galand B, Nils F. The impact of different sources of social support on academic performance: intervening factors and mediated pathways in the case of master's thesis. Revue Europeenne de Psychologie appliquee. 2015; 65: 227-37.

12. Kamenov K, Cabello M, Caballero FF, Cieza A, Sabariego C, Raggi A, Anczewska M, Pitkanen T, Ayuso-Mateos J. Factor related to social support in neurological and mental disorders. PLoS ONE. 2016; 11 (2): e0149356.

13. Rouhani AS, O'Laughlin NK, Faustin MZ, Tsai CA, Kasozi J, Ware CN. The role of social support on HIV testing and treatment adherence: a qualitative study of HIV-infected refuges in Southwestern Uganda. Global Public Health. 2017; 12 (8): 1051-64.

14. Young S, Patterson L, Wolff M, Greer Y, Wynne N. Empowerment, leadership, and sustainability in a faith-based partnership to improve health. Journal of Religious Health. 2015; 54 (6): 2086-98.

15. Hustedde R. An introduction to community development: seven theories for seven community developers. Routledge USA; 2009.

16. Badan Statistik Kota Kupang. Statistik daerah Kota Kupang 2017. Kupang: BPS Kota Kupang; 2017. p. 4-7.

17. Kuntoro. Dasar filosofis metodologi penelitian. Surabaya: Pustaka Melati; 2011.

18. Purnomo W, Bramantoro T. 36 Langkah praktis sukses menulis karya tulis ilmiah. Surabaya: Revka Putra Media; 2014.

19. Hulley BS, Cummings RS, Browner SW, Grady GD, Newman BT. Designing clinical research. Philadelphia: Lippincott Williams and Wilkins; 2013.

20. Boone HN, Boone DA. Analyzing likert data. Journal of Extension. 2012; 50 (2).

21. Shaluhiyah Z, Musthofa BS, Widjarko B. Public stigma to people living with HIV/AIDS. Kesmas: Jurnal Kesehatan Masyarakat Nasional. 2015; 9 (4): 333-9.

22. Rivero-Mendez M, Suarez-Perez EL, Solis-Baez SS. Measuring health literacy among people living with HIV who attend a community-based ambulatory clinic in Puerto Rico. Puerto Rico Health Sciences Journal. 2015; 34 (1): 31-7.

23. Bakhhoum YA, Bachmann OM, Kharrat E, Tallaat R. Assesment of knowledge, attitude, and practice of risky sexual behavior leading to HIV and sexually transmitted infections among Egyptian substance abusers: a cross-sectional study. Advance in Public Health. 2014: 1-8.

24. Sorensen K, Broucke VDS, Fullam J, Doyle G, Pelikan J, Slonska Z, Brand H. Health literacy and public health: a systematic review and integration of definitions and models. BMC Public Health. 2012; 12 (80): 1-13.

25. Moore L, Chersich FM, Steen R, Reza-Paul S, Dhana A, Vuylsteke B, Lafort Y, Scorgie F. Community empowerment and involment of female sex workers in targeted sexual and reproductive health interventions in Africa: a systematic review. Globalization and Health Journal. 2014; 10 (47): 1-17.

26. Blanchard KA, Mohan LH, Shahmanesh M, Prakash R, Isaac S, Ramesh 
MB, Bhattacharjee P, Gurnani MS, Blanchard, FJ. Community mobilization, empowerment and HIV prevention among female sex workers in South India. BMC Public Health. 2013; 13 (234): 1-13.

27. Richards A, Reed J. Social capital's role in the development of volunteer-led cooperatives. Social Enterprise Journal. 2015; 11 (1): 4-23.

28. Frumence G, Erikson M, Nystrom L, Killewo J, Emmelin M. Exploring the role of cognitive and structural forms of social capital in HIV/AIDS trends in the Kagera region of Tanzania - a grounded theory study. African Journal of AIDS Research. 2011; 10 (1): 1-13.

29. Davenport B. Compassion, suffering, and servant-leadership: combining compassion and servant leadership to respond to suffering. Leadership. 2015; 11 (3): 300-15.

30. Spears L. Character and servant leadership: Ten characteristics of effective, caring leaders. The Journal of Virtues and Leadership. 2010; 1 (1): 25-30.

31. Hunt K. Servant leadership: Key principle 9-commiment to the growth of people. Imprint. 2015; 62 (2): 7.

32. Parris D, Peachey J. A systematic literature review of servant leadership theory in organizational contexts. Journal of Business Ethics. 2013; 113 (3): 377-93

33. Benawa A. Servant leadership: Spiritual dimension in leadership. Advanced Science Letters. 2015; 21 (7): 2387-9.

34. Smallwood S, Freedman D, Pitner R, Sharpe P, Cole J, Hastie S, Hunter B. Implementing a community empowerment centre to build capacity for developing, implementing, and sustaining interventions to promote community health. Journal of Community Health. 2015; 40 (6): 11229.

35. Campbell C, Skovdal M, Gibbs A. Creating social spaces to tackle AIDSrelated stigma: reviewing the role of church groups in Sub-Saharan Africa. AIDS Behaviour Journal. 2011; 15 (6): 1204 -19.

36. Weerd W, Timmermans D, Beaujean D, Oudhoff J, Steenbergen J. Monitoring the level of government trust, risk perception and intention of the general public to adopt protective measures during the influenza A (H1N1) pandemic in the Netherlands. BMC Public Health. 2011; 11 (575): 1-12.

37. Radzniwan R, Alyani M, Aida J, Khairania O, Jaafar NRN, Tohid, Hizlinda. Psychological status and its clinical determinants among people living with HIV/AIDS (PLWHA) in Northern Peninsular Malaysia. HIV \& AIDS Review. 2016; 15 (4): 141-6.

38. Baidoobonso S, Bauer G, Speechley K, Lawson E. HIV risk perception and distribution of HIV risk among African, Caribbean and other black people in a Canadian City: mixed methods results from the BLACCH Study. BMC Public Health. 2013; 13 (184): 1-17.

39. Nobakht A, Mohraz M, Rahimzadeh M, Tehranizadeh M, Moghadam $\mathrm{Z}$, Saeieh SE. The effect of cognitive behavioural therapy on depression, anxiety and stress in women with HIV. HIV \& AIDS Review. 2018; 17 (3): 218-23. 